\title{
Three new species of Scolytoplatypus Schaufuss from China, and notes on the movement and functions of the prosternal processes (Coleoptera: Curculionidae: Scolytinae)
}

\author{
HEIKO GEBHARDT ${ }^{1 *}$, ROGER A. BEAVER ${ }^{2} \&$ CHRISTOPH ALLGAIER $^{3}$ \\ ${ }^{1}$ Maienfeldstrasse 23/1,72074 Tübingen, Germany. " gebhardt.heiko@web.de; @ https://orcid.org/0000-0002-7273-4279 \\ ${ }^{2} 161 / 2$ Mu 5, Soi Wat Pranon, T. Donkaew, A. Maerim, Chiangmai 50180, Thailand. \\ झ" roger.beaver6@gmail.com; @il https://orcid.org/0000-0003-1932-3208 \\ ${ }^{3}$ Konzenbergstrasse 10/1, 72074 Tübingen, Germany. \\ "="christoph.allgaier@uni-tuebingen.de; @ https://orcid.org/0000-0001-5577-0801 \\ *Corresponding author
}

\begin{abstract}
Three new species from China (Yunnan), Scolytoplatypus costatus Gebhardt \& Beaver, S. geminus Gebhardt \& Beaver and S. peniculatus Gebhardt \& Beaver, are described and compared with related species of the genus. The male prosternum of Asian Scolytoplatypus species shows species-specific characters, and frequently bears a pair of processes on or close to the anterior margin. We comment here for the first time on the movement of the processes and their likely functions, and survey their occurrence in Asian species of Scolytoplatypus.
\end{abstract}

Key words: Scolytoplatypus, new species, Scolytinae, China, Yunnan, ambrosia beetles

\section{Introduction}

The Scolytoplatypodini is a small tribe of wood-boring ambrosia beetles in the subfamily Scolytinae (Curculionidae), including only two genera, Scolytoplatypus Schaufuss, 1891, and Remansus Jordal, 2013, and 60 described species. The species are outbreeding. The gallery system is started by the female and consists of an entrance gallery leading to one or more circumferential branches in one transverse plane in the outer xylem of the host tree (Beaver \& Gebhardt 2006). The male joins the female soon after the gallery has been started and mating occurs at the gallery entrance. The male then remains in the entrance removing frass, and possibly helping to ventilate the gallery system (Kalshoven 1959). The female continues the construction of the gallery. Eggs are laid in separate egg niches and the larvae excavate their own cradles feeding on a specific ambrosia fungus inoculated by the female (Beaver \& Gebhardt 2006). The adults carry the fungi in a specialized organ, the mycangium, which enables the reliable transmission of the fungus from one generation to the next (Beaver 1989, Beaver \& Gebhardt 2006, Mayers et al. 2020, 2022).

The distribution area of the genus Scolytoplatypus includes continental Africa, Madagascar and Asia, extending eastwards to New Guinea (Schedl 1975). Their Asian range includes highly diverse climatic zones from Sakhalin island to the tropical rainforests of Indonesia. The genus exhibits its greatest taxonomic diversity in Asia, and major revisions of the Asian species were published by Schedl (1975) and Beaver \& Gebhardt (2006). During the last 15 years, several new species have been described (Beaver \& Liu 2007, Knížek 2008, Maiti \& Saha 2009), and a synonym was reinstated as distinct species on the basis of new data (Mandelshtam \& Petrov 2010). Browne (1971) published a revised classification of the African species, and the number of described species has since reached 13 (Schedl 1975, Jordal 2018). Closer scrutiny of the Madagascan species led to the separation of the genus Remansus (Jordal 2013) for the majority of the species found in Madagascar. The latter genus differs from Scolytoplatypus by a flat rather than depressed scutellum in both sexes (Jordal 2013). None of the Scolytoplatypus species is endemic to more than one of the three geographic regions (Schedl 1975). Morphological characteristics 
and molecular genetic data suggest a common divergence of the Asian Scolytoplatypus species from those prevalent in Africa and Madagascar (Beaver \& Gebhardt 2006, Jordal 2013). In contrast to the African/Madagascan species, the males of the Asian Scolytoplatypus species show a complex prosternal morphology while the female prosternum exhibits a characteristic posterior constriction (Beaver \& Gebhardt 2006). Moreover, the female mycangia have specific internal features (Schedl 1962, Mayers et al. 2020). These conclusions based on morphology and DNA are backed up by phylogenetic investigations of the symbiotic fungal species present in Scolytoplatypodini (Mayers et al. 2020). These have revealed that they do not belong to a monophyletic group, but that Asian and African Scolytoplatypus species utilize different genera of ambrosia fungi (Mayers et al. 2020). It has, therefore, been suggested that the Asian species of Scolytoplatypus should be separated as a distinct genus (Mayers et al. 2020), but we prefer not to do so at this time.

Here we describe three new Scolytoplatypus species from collections made in Southwest China (Yunnan). We note for the first time that the prosternal processes of the males of many of the Asian species of Scolytoplatypus can be moved by the beetle, and could possibly be used in species and sexual recognition, and in courtship behaviour.

\section{Material and methods}

The specimens described as new species in this study were collected by Dr. L-Z Meng (Honghe University, Yunnan) as part of an extensive project involving trapping in many locations in different forest types, and at different altitudes in Yunnan. They were made available to the authors by Dr. Meng. Specimens have also been examined in the Natural History Museum, London, the Naturhistorisches Museum, Wien, and other museums, and in the collections of the two senior authors.

Photographs were taken with a Canon EOS 600D digital camera using Mitutoyo M Plan Apo microscope lenses. Images and image layers were processed with Zerene Stacker 1.04 software (Zerene Systems, Richland, WA, USA).

The species described in this article are preserved in the following collections:

CAS Institute of Zoology, Chinese Academy of Sciences, Beijing, China

HGT Private collection, Heiko Gebhardt, Tübingen, Germany

NHMW Naturhistorisches Museum, Wien, Austria

NHMUK Natural History Museum, London, United Kingdom

RAB Private collection, Roger Beaver, Chiangmai, Thailand

\section{Taxonomy}

\section{Scolytoplatypus costatus Gebhardt \& Beaver sp. nov.}

Fig. 1A-F, 2A

Type material. Holotype: male: CHINA, Yunnan, Puer, Jingdong, Ailoshan, 24.516N, 101.01E, 2356 m, ALS22004FI, 8.v.2018, L.Z. Meng (CAS). Paratypes: as holotype (CAS, 1f), as previous except, 24.517N, 101.012E, 2377m, FIT, ALS2200-1FI, (RAB 1m, 1f); as previous except: 24.515N, 101.011E, 2374m, ALS2200-3FI (RAB 1m); as previous except: $24.532 \mathrm{~N}, 101.015 \mathrm{E}, 2499 \mathrm{~m}$, ALS(S)2400-2FI, (RAB 2m); as previous except: $24.517 \mathrm{~N}, 101.011 \mathrm{E}$, 2374m, ALS2200-3FI, 28.v.2018 (NHMUK 1m, 2f; HGT 1f).

Diagnosis. The species is distinguished by the lack of a tooth on the upper side of the profemur, and the presence of small spines on the interstriae of the elytral declivity. It resembles $S$. blandfordi Gebhardt and related species in its elongate body with elytra about 1.7-2.0 times as long as pronotum, elytral declivity beginning in apical third of elytra, and prosternum raised in a triangle with apex anterior. It can be distinguished from all these species, except $S$. zahradniki Knižek, by the presence of carinate and spinose interstriae in both sexes, and the female pronotum without a mycangial pore. It is distinguished from $S$. zahradniki by the male prosternum anteriorly with two processes like long pointed spines with slightly outwardly curved tips (Fig. 2A), compared to two curved falcate processes in S. zahradniki (Fig. 2D). 

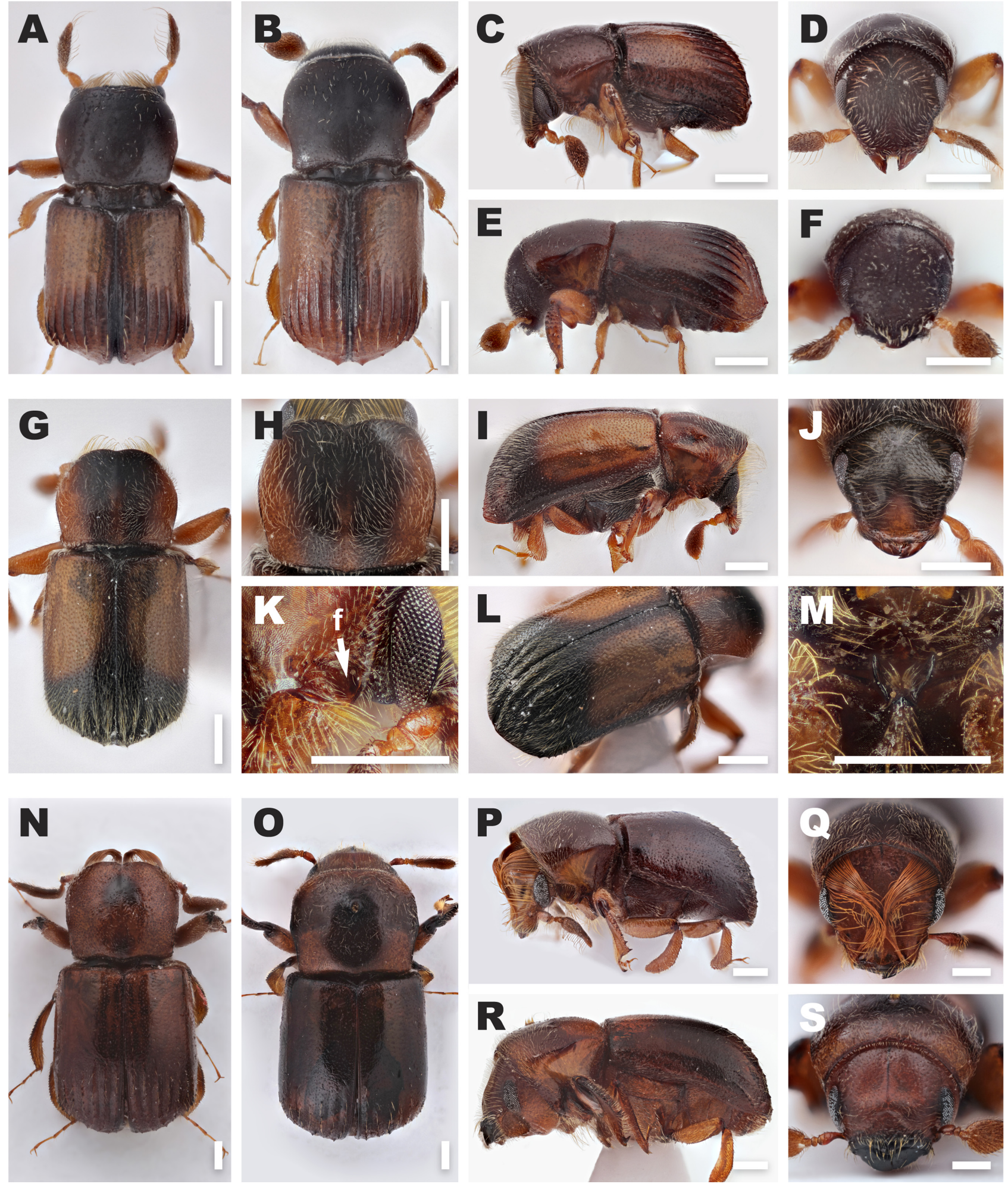

FIGURE 1. Habitus and details of Scolytoplatypus spp. nov.: S. costatus male (2.2-2.3 mm), habitus dorsal (A), habitus lateral (C), frons anterior (D); S. costatus female (2.3-2.4 mm), habitus dorsal (B), habitus lateral (E), frons anterior (F); S. geminus male $(2.9-3.3 \mathrm{~mm})$, habitus dorsal $(\mathrm{G})$, pronotum $(\mathrm{H})$, habitus lateral $(\mathrm{I})$, frons anterior $(\mathrm{J})$, pronotum anteroventral with $\mathrm{f}=$ fovea $(\mathrm{K})$, declivity (L), prosternum (M); S. peniculatus male (4.7-4.8 mm), habitus dorsal (N), habitus lateral (P), frons anterior (Q); S. peniculatus female (4.9-5.3 mm), habitus dorsal (O), habitus lateral (R), frons anterior (S). The bars represent $0.5 \mathrm{~mm}$. 

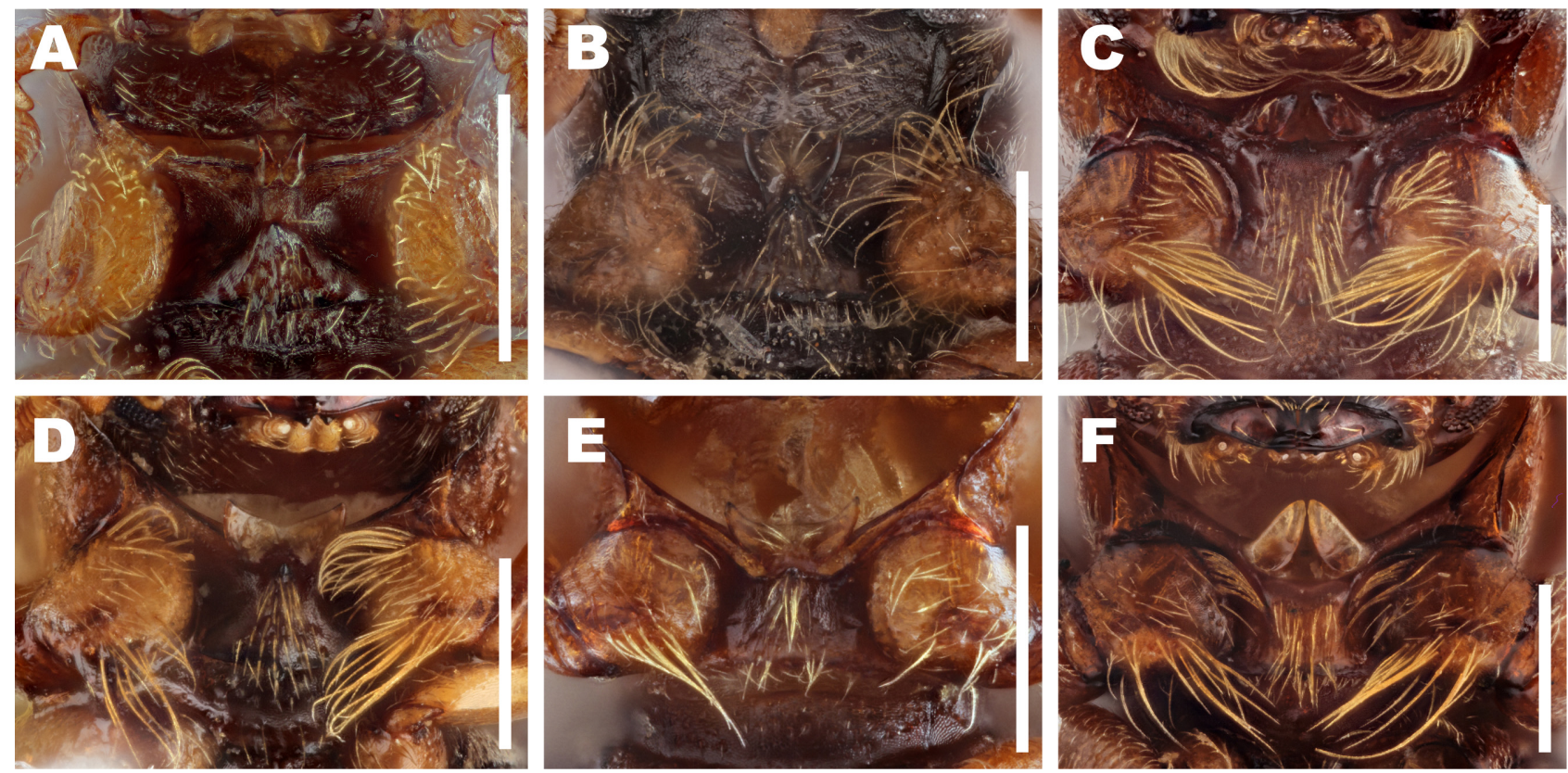

FIGURE 2. Male prosternum of Scolytoplatypus costatus, S. geminus and S. peniculatus in comparison to their close relatives: S. costatus (A), S. geminus (B), S. peniculatus (C), S. zahradniki (D), S. blandfordi (E), S. pubescens (F). The bars represent $0.5 \mathrm{~mm}$.

\section{Description:}

Male: $2.2-2.3 \mathrm{~mm}$ long, about 1.8-1.9 times as long as wide, bicoloured, brown to dark brown, head dark brown, pronotum dark brown, sometimes partly lightened, elytra brown with varying dark brown coloration, especially along the suture, the base, the sides and at the declivity summit.

Frons. Concave, reticulate, rather sparsely punctured, more densely at margins, a small median area above epistoma almost impunctate, the punctures bearing fine, yellowish semi-appressed setae directed dorsally, and in the lower half of the frons toward the midline, the lateral and upper margins with longer, erect, hairlike setae curving towards the middle of the frons.

Antennal club. 1.9 times as long as wide, elongate and triangular, widest near the base, acuminate, densely covered with short appressed setae, anteroventral margin and the tip with long, erect setae.

Pronotum. 1.2 times wider than long, anterior margin with a deep, wide emargination in the middle, anterior angles broadly rounded, sides widest behind the middle, constricted to the base, posterior margin bisinuate, posterolateral angles almost rectangular, dorsal surface reticulate, with sparse, fine puncturation, with sparse, yellowish setae anteriorly, posteriorly nearly glabrous, anteroventral angles with a deep, almost circular fovea extending to ventral margin.

Prosternum. Posteriorly raised in a flat triangle, its apex anterior, anterior to the tip of the triangle, a short median ridge ending in a pair of small, swollen processes which are prolonged anteriorly into sharply pointed spines diverging at about $60^{\circ}$.

Procoxae. Flattened anteriorly, slightly swollen posteriorly, with coarse, yellow setae, longer and denser at the anterior tip and the posterior margin, the longest hairs a little longer than the length of the procoxa, not forming a distinct brush.

Elytra. 1.1 times longer than wide, 1.7-2.0 times longer and slightly wider than pronotum, scutellum sunken, elytral bases straight, sides subparallel on anterior three-fourths, then rounded to the apex, viewed from the side, the declivity slope begins about two-thirds from base, elytral surface on anterior half smooth, glabrous and minutely reticulate, striae inconspicuous, interstriae not punctured, becoming carinate after middle of elytral disc, the carinae becoming weaker on the declivity summit, but those of interstriae 1, 3,6-8 visible up to the middle of the declivity, interstriae 1 and 3 diverging from midline in lower half of declivity, and bearing a few small spines, stronger on interstriae 1 with a larger pair close to elytral apex, striae visible as lines of punctures, lower part of declivity glabrous and otherwise smooth, lateral margins of declivity formed by the carinate interstriae 9 which extend to the declivital apex, and are armed laterally with small spines. 
Female: $2.3-2.4 \mathrm{~mm}$ long, about 2 times as long as wide, coloration as in male.

Frons. Convex, triangularly impressed above the epistoma, upper part with a fine vertical, median carina, whole surface reticulate with fine, sparse punctures bearing short, semi-appressed, fine setae.

Antennal club. Elongate oval, 1.6 times as long as wide, with appressed setae, a few long setae at the tip.

Pronotum. Similar to male but a little more elongate, 1.1 times as wide as long, anterior margin with emargination shallower than in male, anterior angles arcuate, pronotal disc impressed in midline just before the middle, but without a mycangial pit; anteroventral angles without a fovea.

Prosternum. Flattened with punctures and appressed setae.

Procoxae. Smaller than in male and lacking long, coarse setae.

Elytra. Generally as in male, the interstrial carinae slightly weaker, and the spines smaller.

Distribution. China (Yunnan). A montane species found only above $2300 \mathrm{~m}$.

Etymology. Derived from the elevated ridges on the elytra (Latin: costatus = ribbed).

Host plants. Unknown

\section{Scolytoplatypus geminus Gebhardt \& Beaver sp. nov.}

Fig. 1G-M, 2B

Type material. Holotype: male: CHINA, Yunnan, Lijiang, 27.1433N, 100.2266E, 3221 m, 18.v.2018, G02, LJ(X)3200-4FI, L.Z. Meng (CAS, 1m). Paratypes: as previous except: 27.1435N, 100.2261E, 3244m, 28.vi.2018, $\mathrm{LJ}(\mathrm{X}) 3200-3 \mathrm{FI}$ (RAB, 1m); as previous except: 27.1663N, 100.2350E, $3551 \mathrm{~m}$, 28.v.2018, LJ(X)3600-5FI (CAS, $2 \mathrm{~m}$; RAB, 3m); as previous except: 27.1657N, 100.2354E, $3545 \mathrm{~m}, 3 . v i .2018, \mathrm{LJ}(\mathrm{X}) 3600-3 \mathrm{FI}$ (NHMUK, 3m; NHW, 3m; HGT, 3m).

Diagnosis. The species is distinguished from most Asian species of Scolytoplatypus by the lack of a tooth on the upper side of the profemur, and the absence of spines or teeth at the summit of the elytral declivity. It is most closely similar to $S$. blandfordi Gebhardt, which it resembles in its elongate body with elytra about 1.7-2.0 times as long as pronotum, elytral declivity beginning in apical third of elytra, and prosternum raised in a triangle with apex anterior. However, it is distinguished from S. blandfordi by characters of the male frons and anterior processes of the prosternum. In S. geminus, lower half of frons shining, slightly gibbous towards sides at level of antennal insertions; marginal fringe of setae on upper half of the frons short, with tips of setae rarely reaching midline, and not overlapping; underlying hairlike setae forming the vestiture below the marginal fringes more numerous, more closely placed, longer and finer. In S. blandfordi, lower half of frons matt, not gibbous towards sides; marginal fringe of setae on upper part of the frons much longer, setae meeting in midline and slightly overlapping; setae forming underlying vestiture less closely placed, shorter and slightly coarser. In S. geminus, anterior end of raised prosternal triangle ends in a sharply pointed projecting tip; anterior processes of prosternum directed anteriorly, diverging at an angle of about $60^{\circ}$ (Fig. 2B). In S. blandfordi, anterior tip of raised prosternal triangle rounded or truncate; anterior processes directed laterally, diverging at an angle of about $160^{\circ}$ (Fig. 2E).

\section{Description:}

Male: $2.9-3.3 \mathrm{~mm}$ long, about 2.1 times as long as wide, yellowish-brown to brown, anterior half of pronotum, elytral suture, margins and declivity usually darker.

Frons. Concave, lower half shining, the whole surface minutely reticulate, a triangular area above the epistoma glabrous and unpunctured, slightly gibbous on each side at the level of the antennal insertions, the surface above the triangle finely, moderately densely punctured, bearing grey-white, fine, hairlike setae directed towards the midline, the setae erect at margins of frons, becoming appressed towards centre, but with upwardly curved tips near midline; margin from top of eye to near the vertex with longer, incurved, pale yellowish fine hair-like setae, their tips not reaching the middle of the frons.

Antennal club. 1.8 times longer than wide, nearly oval, widest near the middle, the surface covered with pale, appressed hairs, apex with a few, long, dark setae, anterior margin with a row of, widely separated, long, strong, dark setae.

Pronotum. 1.2 times wider than long, anterior margin with a median emargination, pronotum widest just before the middle, constricted posteriorly, posterior angles moderately pointed, posterior margin slightly produced in the middle, surface minutely reticulate, finely, distantly punctured, the punctures usually separated by $3-5$ times their 
diameter, towards the posterior margin more densely punctured, surface on the anterior two-thirds with semi-erect hairlike setae directed posteriorly, setae on posterior portion more appressed, shorter, those near mid-line directed laterally, anteroventral angles with an orbicular fovea extending to anterior and ventral margins.

Prosternum. Triangularly raised in the middle, apex of triangle anterior and sharply pointed, punctures with setae directed posteriorly, anterior to apex of triangle with two curved falcate processes, with sharply pointed tips, diverging at an angle of about $60^{\circ}$, between them a very small, rounded process with numerous setae.

Procoxae. Flattened anteriorly, slightly swollen posteriorly, with coarse, yellow setae, longer and denser at the anterior tip and the posterior margin, the longest hairs a little longer than the length of the procoxa, not forming a distinct brush.

Elytra. 1.3-1.4 times longer than wide, about two times longer than pronotum, wider than pronotum, scutellum sunken, from dorsal view sides nearly straight, weakly diverging, on posterior fourth strongly converging to the rounded apex, from lateral view the convex declivity beginning about three-fourths from base, elytral base carinate, disc shining, striae and interstriae indistinct, with irregular, fine, punctures, bearing short, yellowish, erect hairlike setae; towards declivity, setae longer, and punctures more densely placed and larger; on summit of declivity punctures closely spaced, declivity dull with distinct and moderately close punctures, setae on upper part long, erect, towards the apex shorter and appressed, declivity with feebly impressed striae, interstriae densely rugulose-granulate on upper part, on lower part interstriae 1, 3 and 5 with a row of larger granules, apical margin carinate, with small, acutely pointed spines laterally on interstriae 9 .

Female: Not known. Probably very similar to that of S. blandfordi.

Distribution. China (Yunnan). A montane species found only above $3000 \mathrm{~m}$.

Etymology. The name refers to the similarity to Scolytoplatypus blandfordi Gebhardt, from the Latin geminus $=$ twin

Host plants. Unknown.

\section{Scolytoplatypus peniculatus Gebhardt \& Beaver sp. nov.}

Fig. $1 \mathrm{~N}-\mathrm{S}, 2 \mathrm{C}$

Type material. Holotype: male: CHINA: Yunnan, Puer, Jingdong, Ailoshan, 2682 m, 24.5406N 101.0304E, leg. L.Z. Meng, 28.V.2018 (CAS, 1m). Paratypes: As holotype (CAS, 2f; NHMUK, 1m, 2f; NHMW, 1f); as previous except: 24.532N, 101.015E, 2499 m, 30.v.2018, ALS(X)2400-2FI (RAB, 1m); as previous except: $24.541 \mathrm{~N}, 101.030 \mathrm{E}$, $2681 \mathrm{~m}, 30 . \mathrm{v} .2018$, ALS(X)2600-4FI (RAB,1m); as previous except: 24.540N, 101.031E, $2683 \mathrm{~m}$, 11.v.2018, FIT, ALS2600-3FI (RAB, 2f); as previous except: Honghe, Hekou, Dajianshan, 22.908N. 103.697E, 2137 m, 1.v.2018, DJS3-2 (RAB, 1m); as previous except: 2111 m, FIT, DJS1-2 (HGT, 1m, 1f; RAB, 1f).

Diagnosis. This species is the largest known species of Scolytoplatypus, with males 4.7-4.8 $\mathrm{mm}$ long, and females $4.9-5.3 \mathrm{~mm}$, and can be distinguished by size alone. It lacks a profemoral tooth, and has small interstrial spines near the summit of the elytral declivity. The basal angles of the pronotum are not produced. It is most closely similar to $S$. pubescens Hagedorn. It resembles that species in the male frons with an area of dense, short hairs in the middle and a male prosternum with two triangular processes anteriorly. The males can be distinguished by a prosternum with obtuse triangular processes (Fig. 2C), in contrast to elongated, acute triangular processes in $S$. pubescens (Fig. 2F) In both sexes of S. peniculatus, the declivity lacks the dense vestiture present in S. pubescens, and all interstriae bear a single row of spines, each with a single, long, erect seta.

Description:

Male: $4.7-4.8 \mathrm{~mm}$ long, about 1.9 times as long as wide, castaneous to dark brown.

Frons. Concave, surface shining, glabrous above the epistoma, otherwise punctured, more coarsely towards the apex, centrally with an oval area of very dense, short pubescence, the lateral margins in the lower part with a row of long hairs curving towards the midline, next to and above the upper part of the eyes a brush of long, yellowishbrown hairs curving downwards on each side towards the midline, the brushes overlapping medially and extending to the epistomal margin, the brushes separated dorsally by about the width of the anterior pronotal emargination.

Antennal club. 2.3 times as long as wide, elongate triangular widest near the base, acuminate, densely covered with short appressed setae, anteroventral margin with long, erect setae.

Pronotum. 1.2 times as wide as long, dorsal surface minutely reticulate, with fine punctures bearing fine, 
yellowish setae over the whole surface, the setae longer anteriorly, anterior margin convex with a median emargination, anterior angles broadly rounded, pronotum widest in anterior quarter, the sides gradually narrowing to the slightly produced posterior angles, posterior margin bisinuate; pronotum with a large, deep, approximately triangular fovea at the anteroventral angle, extending to the anterior and ventral margins.

Prosternum. Posterior part slightly raised medially, and with a small triangular projection in the midline at the posterior margin, granulate-punctate with long coarse yellowish hairs directed posteriorly, anterior margin almost straight without a median projection, with two oblique, widely separated, moveable triangular processes, their tips directed towards each other.

Procoxae. Flattened anteriorly, slightly swollen posteriorly, with coarse, yellow setae, longer and denser at the posterior margin, forming a loose brush, the longest hairs nearly 1.5 times longer than the length of the procoxa.

Elytra. 1.2 times longer than wide, 1.7 times longer than the pronotum, wider than pronotum, scutellum sunken, elytral bases straight, sides subparallel on anterior three-fourths, only slightly widened towards the apex, abruptly rounded behind, in lateral view the convex declivity beginning about three-fourths from base, elytral surface shining, glabrous, irregularly punctate to top of declivity, declivity with interstriae elevated, shining and finely carinate close to top, ventrally the carinae replaced on all interstriae by a single row of backwardly-pointing spines, each bearing a single, long, erect seta inserted just behind the spine, the rows on interstriae 1-3 extending to the apex; remainder of declivital surface dull and rugulose.

Female: $4.9-5.3 \mathrm{~mm}$ long and about 1.9 times as long as wide, castaneous to dark brown.

Frons. Convex, above the epistoma with a triangularly impressed area, with a central carina, surface microreticulate, with fine punctures bearing setae.

Antennal club. Oval, coarsely hairy, 1.4 times as long as wide.

Pronotum. 1.25 times as wide as long, widest in the middle, constricted posteriorly, dorsal surface minutely reticulate, finely punctured, median emargination much shallower than in male, mycangial pit in midline in anterior half, oval, a narrow area around it glabrous, otherwise with sparse, long, yellowish setae, shorter posteriorly; anteroposterior angle without a fovea.

Prosternum. Flattened, punctate, with posteriorly-directed setae.

Procoxae. Smaller than in male, flattened, the setae shorter and less abundant, not forming a brush.

Elytra. Generally as in male, but without carinae on interstriae at the top of the declivity.

Distribution. China (Yunnan). A montane species found only above $2000 \mathrm{~m}$.

Etymology. Referring to the pubescent area on the frons which is reminiscent of a brush (Latin: peniculus $=$ brush)

Host plants. Unknown.

\section{Male prosternum: morphology and function}

One of the most important means by which the Asian species of Scolytoplatypus can be distinguished is the morphology of the male prosternum (Blandford 1896, Beaver \& Gebhardt 2006). This is variously developed and differentiated, and its form is species-specific. The prosternum is often characterised by the presence of a pair of processes at the anterior end (Figs 1-2 in Beaver \& Gebhardt 2006). It has been assumed that the processes are passive, and remain in the position in which they are normally found in dead specimens. However, we have discovered that in many Oriental species, the processes are, in fact, capable of independent movement in both horizontal and vertical planes. In most species the base of each process is surrounded by pale, flexible, unsclerotised cuticle. Dissection reveals that muscles are attached independently to the base of each process, enabling independent movement. The basal part of the process bears sensory setae, and the tips are often pointed or hooked (Fig. 3A-C).

A survey of the Asian species of Scolytoplatypus (Table 1) shows that moveable processes are present in the majority (22 ex 38; 58\%) of species. In six species, it remains unclear whether the processes are moveable or fixed. We did not have access to males of three of these species (S. gardneri, S. kunala, S. nitidicollis), and dissection will be necessary to determine whether or not the processes can be moved in the other three species ( $S$. daimio, $S$. darjeelingi, S. eutomoides). One species (S. ruficauda) is unusual in possessing asymmetrical processes. The right process of this species is larger than the left, but neither process appears to be moveable. Nine of the species lack prosternal processes. 

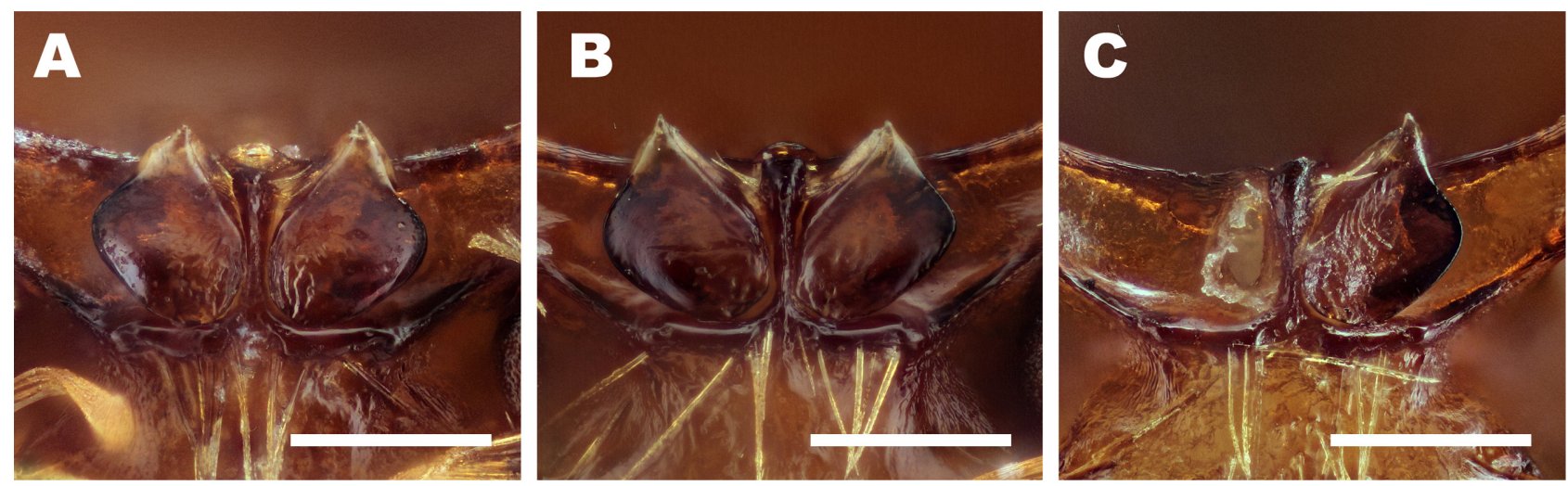

FIGURE 3. Male prosternum of Scolytoplatypus brahma Blandford with moveable processes: (A) right process moved in vertical plane slightly to the right; (B) left process moved in vertical plane slightly to the left; (C) left process removed to show flexible, unsclerotised cuticle at the base of the process. The bars represent $0.2 \mathrm{~mm}$.

We suggest that in the species with moveable processes, (i) the processes are moved during courtship and premating behaviour, (ii) that they are involved in both species and sexual recognition, and (iii) they serve to provide sexual stimulation of the female. Morphological characters playing a role in mating behaviour of scolytine beetles commonly show rapid evolution (Kirkendall et al. 2015), so the great variety of prosternal morphology is perhaps not surprising. Behavioural studies of mating pairs will be necessary to determine the validity of our hypotheses.

The prosternal processes appear to be an evolutionary adaptation confined to some of the Asian species of Scolytoplatypus. They are not found in the African species of Scolytoplatypus, nor in the Madagascan genus Remansus; nor, so far as we know, do they occur in other tribes of Scolytinae. At present it is not clear whether the processes have evolved more than once within the group. Clarification awaits a detailed phylogenetic analysis of both Asian and African species of Scolytoplatypus based on DNA analyses.

TABLE 1. Asian species of Scolytoplatypus in which prosternal processes are moveable, not moveable, uncertainly moveable or absent.

\begin{tabular}{|c|c|}
\hline $\begin{array}{l}\text { Prosternal pro- } \\
\text { cesses }\end{array}$ & Scolytoplatypus species \\
\hline $\begin{array}{l}\text { Moveable } \\
(22 \text { species })\end{array}$ & $\begin{array}{l}\text { S. blandfordi Gebhardt, bombycinus Browne, brahma Blandford, calvus Beaver \& Liu, carinatus } \\
\text { Bright, costatus Gebhardt \& Beaver sp. n., geminus Gebhardt \& Beaver sp. n., javanus Eggers, } \\
\text { luzonicus Eggers, macgregori Blackman, mikado Blandford, minimus Hagedorn, nitidus Eggers, } \\
\text { peniculatus Gebhardt \& Beaver sp. n., pubescens Hagedorn, raja Blandford, reticulatus Bright, } \\
\text { samsinghensis Maiti \& Saha, shogun Blandford, sinensis Tsai \& Huang, superciliosus Tsai \& } \\
\text { Huang, zahradniki Knížek }\end{array}$ \\
\hline $\begin{array}{l}\text { Uncertain } \\
(6 \text { species })\end{array}$ & $\begin{array}{l}\text { S. daimio Blandford, darjeelingi Stebbing, eutomoides Blandford, gardneri Maiti \& Saha, kunala } \\
\text { Strohmeyer, nitidicollis Eggers }\end{array}$ \\
\hline $\begin{array}{l}\text { Not moveable } \\
(1 \text { species })\end{array}$ & S. ruficauda Eggers \\
\hline $\begin{array}{l}\text { Absent } \\
(9 \text { species })\end{array}$ & $\begin{array}{l}\text { S. cirratus Gebhardt, curviciliosus Gebhardt, exiguus Beaver, glaber Eggers, lopchuensis Maiti \& } \\
\text { Saha, nanus Schedl, parvus Sampson, pusillus Eggers, tycon Blandford }\end{array}$ \\
\hline
\end{tabular}

\section{Acknowledgements}

We are most thankful to L.Z. Meng (Honghe University, Yunnan) for providing specimens from his collected material for this investigation. Harald Schillhammer facilitated and supported our work when visiting the collection of the Naturhistorisches Museum, Wien, and we also thank him for the loan of species. We are grateful to Andreas Weigel, Matthias Hartmann (Naturkundemuseum, Erfurt), Max Barclay (Natural History Museum, London), Arnaud 
Faille (Naturkundemuseum, Stuttgart) and Hume Douglas (Canadian National Collection of Insects, Arachnids and Nematodes, Ottawa) for providing material from their respective collections. We also thank Milos Knížek for the loan of paratypes of Scolytoplatypus zahradniki.

\section{References}

Beaver, R.A. (1989) Insect-fungus relationships in the bark and ambrosia beetles. In: Wilding, N., Collins, N.M., Hammond, P.M. \& Webber, J.F. (Eds.), Insect-Fungus Interactions. Academic Press, New York, pp. 121-143. https://doi.org/10.1016/B978-0-12-751800-8.50011-2

Beaver, R.A. \& Gebhardt, H. (2006) A review of the Oriental species of Scolytoplatypus Schaufuss (Coleoptera, Curculionidae, Scolytinae). Deutsche Entomologische Zeitschrift, 53, 155-178. https://doi.org/10.1002/mmnd.200600014

Beaver, R.A. \& Liu, L.-Y. (2007) A new species of Scolytoplatypus Schaufuss (Coleoptera: Curculionidae: Scolytinae) from Taiwan. Entomologist's Monthly Magazine, 143, 227-231.

Blandford, W.F.H. (1896) Descriptions of new Scolytidae from the Indo-Malayan and Austro-Malayan regions. Transactions of the Entomological Society of London, 1896, 191-228. https://doi.org/10.1111/j.1365-2311.1896.tb00962.x

Browne, F.G. (1971) The African species of Scolytoplatypus Schaufuss (Coleoptera: Scolytidae). Revue de Zoologie et de Botanique Africaines, 84, 111-129.

Jordal, B.H. (2013) Deep phylogenetic divergence between Scolytoplatypus and Remansus, a new genus of Scolytoplatypodini from Madagascar (Coleoptera, Curculionidae, Scolytinae). ZooKeys, 352, 9-33. https://doi.org/10.3897/zookeys.352.6212

Jordal, B.H. (2018) The smallest known species of Afrotropical Scolytoplatypus Schaufuss (Curculionidae, Scolytinae)—with unique features and an isolated phylogenetic position. ZooKeys, 749, 125-130. https://doi.org/10.3897/zookeys.749.24199

Kalshoven, L.G.E. (1959) Studies on the biology of Indonesian Scolytoidea 4. Data on the habits of Scolytidae. Second part. Tijdschrift voor Entomologie, 102, 135-173, pls. 15-22.

Kirkendall, L.R., Biedermann, P.H.W. \& Jordal, B.J. (2015) Evolution and diversity of bark and ambrosia beetles. In: Vega, F.E. \& Hofstetter, R.W. (Eds.), Bark beetles, biology and ecology of native and invasive species. Elsevier, Amsterdam, pp. $85-156$. https://doi.org/10.1016/B978-0-12-417156-5.00003-4

Knížek, M. (2008) A new species of Scolytoplatypus (Coleoptera: Scolytidae) from China. Studies and reports of District Museum Prague-East. Taxonomical Series, 4, 119-124.

Maiti, P.K. \& Saha, N. (2009) Fauna of India and the adjacent countries: Scolytidae: Coleoptera (Bark-and Ambrosia-Beetles). Vol. 1. Part 2. Zoological Survey of India, Kolkata, 246 pp.

Mandelshtam, M.Y. \& Petrov, A.V. (2010) Description of new Dryocoetes (Coleoptera, Curculionidae, Scolytinae) species from Afghanistan and Northern India and redescription of Scolytoplatypus kunala Strohmeyer. ZooKeys, 56, 179-190. https://doi.org/10.3897/zookeys.56.525

Mayers, C.G., Harrington, T.C., Masuya, H., Jordal, B.H., McNew, D.L., Shih, H.-H., Roets, F. \& Kietzka, G.J. (2020) Patterns of coevolution between ambrosia beetle mycangia and the Ceratocystidaceae, with five new fungal genera and seven new species. Persoonia, 44, 41-66. https://doi.org/10.3767/persoonia.2020.44.02

Mayers, C.G., Harrington, T.C., Biedermann, P.H.W. (2022) Mycangia define the diverse ambrosia beetle-fungus symbiosis. In: Schultz, T.R., Peregrine, P.N., Gawne, R. (Eds.), The Convergent Evolution of Agriculture in Humans and Insects. MIT Press, Cambridge, MA. pp. 1-38. [in press, ISBN-13: 9780262543200]

Schaufuss, C.F.C. (1891) Beitrag zur Käferfauna Madagascar's II. Tijdschrift voor Entomologie, 34, 1-35.

Schedl, K.E. (1975) Die Unterfamilie Scolytoplatypinae (Coleoptera, Scolytidae). Entomologische Abhandlungen Staatliches Museum für Tierkunde in Dresden, 40, 199-267.

Schedl, W. (1962) Ein Beitrag zur Kenntnis der Pilzübertragung bei xylomycetophagen Scolytiden. Sitzungsberichte der Österreichischen Akademie der Wissenschaften Wien, Mathematische-naturwissenschaftliche Klasse, Abteilung 1, 171, 363-387. https://doi.org/10.1007/978-3-662-25975-7_1 